\title{
Applicability Assessment of Electrocoagulation in Real Dyeing Wastewater Treatment
}

\author{
D.P. Hung*, L.T.K Oanh*, V.T.D. Chi*, L.N.Q. Thinh*, D.T. Nguyen*, N.Q. Tuan* and H.T.N. Han**† \\ *Department of Technology, Van Lang University, Ho Chi Minh City, 700000, Vietnam \\ **Department of Environment, Ho Chi Minh City University of Natural Resources and Environment, Ho Chi Minh City, \\ 700000, Vietnam \\ $\dagger$ Corresponding author: H.T.N. Han; han.htn_mt@hcmunre.edu.vn
}

Nat. Env. \& Poll. Tech.

Website: www.neptjournal.com

Received: 05-03-2020

Revised: 31-05-2020

Accepted: $21-06-2020$

Key Words:

Electrocoagulation Iron electrodes

Real dyeing wastewater

Wastewater treatment

\begin{abstract}
In this study, the applicability of electrocoagulation using iron electrodes in real dyeing wastewater treatment was assessed based on pollutants removal efficiency, sludge generation, energy consumption and operation cost in practice. The effects of current density, $\mathrm{pH}$, conductivity, and reaction time on treatment performance were evaluated. The operation cost of electrocoagulation was calculated including the energy cost, the iron plate cost, generated sludge treatment cost, and added substances cost. The results indicated that the colour, CODcr and TSS removal efficiencies were high and quite stable with short reaction time (reached $92.07 \pm 1.21 \%, 65.7 \pm 1.47 \%$, and $89.8 \pm 1.2 \%$, respectively, with only $15 \mathrm{~min}$ ). Average sludge generation, specific energy consumption, and operation cost were determined respectively as $0.645 \pm 0.0543 \mathrm{~kg} / \mathrm{m}^{3}, 1.182 \mathrm{kWh} / \mathrm{m}^{3}$ and $0.517 \mathrm{USD} / \mathrm{m}^{3}$. Coagulationflocculation using $\mathrm{FeSO}_{4}$ was performed as a control experiment as well. Compared to coagulationflocculation, electrocoagulation has the same removal efficiency but has less generated sludge (only $50 \%$ ) and little to no added chemicals. Therefore, the operating cost was quite less than the others, with only $0.517 \mathrm{USD} / \mathrm{m}^{3}$ instead of $1.99 \mathrm{USD} / \mathrm{m}^{3}$ (equal to $1 / 3.5$ ).
\end{abstract}

\section{INTRODUCTION}

The real dyeing wastewater has usually extremely variable characteristics depending on the kind of dyes used and production capacity according to customer orders. It is highly coloured and viscous caused by residual dye and suspended solids. It also contains a lot of sodium and chloride ions due to high sodium chloride consumption in processing units (Hussain et al. 2004). In general, developing countries and namely, in Vietnam, the conventional and popular treatment method applied in primary treatment to remove colour and TSS (Total suspended solid) in dyeing wastewater is coagulation-flocculation-sedimentation. However, the amount of generated hazardous sludge and high chemical consumption are the biggest problems of this method.

Electrocoagulation (EC) is well known as the method that can remove colour, COD (chemical oxygen demand), TSS in the textile wastewater by electrolysis reaction using iron or aluminium or stainless steel electrodes. The pollutants can be removed by flocculation, adsorption of contaminants on flocs, sedimentation and floatation in the EC process. Iron electrodes out-performed others (Wang et al. 2016). Easy operation, none used chemicals, low sludge settling time, and less sludge formation are the main advantages of electrocoagulation technology (Khorram \& Fallah 2018, Chaturvedi \& Satish 2013).

In recent years, most results of the previous studies on electrocoagulation using iron or aluminium electrodes to remove various dye types in textile wastewater showed that the dye and colour removal efficiencies were too high, from $83 \%$ to $100 \%$. Each dye type in synthetic wastewater had a different optimal operating condition when treated by the electrocoagulation method. The operating factors significantly affected the treatment performance of dyeing wastewater such as current density, $\mathrm{pH}$, conductivity, and reaction time (Aleboyeh et al. 2008, Arslan-Alaton et al. 2009, Charroenlarp \& Choyphan 2009, Daneshvar et al. 2003, 2007, Kashefialasl et al. 2006, Khandegar \& Saroha 2013, Khorram \& Fallah 2018, Ahmed et al. 2018, Wang et al. 2016, Korbahti et al. 2011, Huynh et al. 2016, Parsa et al. 2011, Yang \& McGarrahan 2005, Yuksel et al. 2013). Although the previous studies illustrated that electrocoagulation was able to remove dye and colour with high performance, most of these researches were performed with synthetic wastewater containing a specific dye. Therefore, it is difficult to apply these results to the general practical treatment of real wastewater containing various pollutant's concentration with different kinds of dye. In this study, the 
electrocoagulation method using iron electrodes to treat the real dyeing wastewater from textile manufactory was investigated. The effect of $\mathrm{pH}$, current density, reaction time, and conductivity was evaluated to find out the optimal operating condition. The treatment efficiency, sludge generation, energy consumption, and operation cost of the EC process were determined. In addition, the coagulation-flocculation method using $\mathrm{FeSO}_{4}$ was performed as a control experiment. A comparison of the electrocoagulation method and conventional method based on generated sludge, specific energy consumption, and operation cost were evaluated to provide a scientific basis for selecting and replacing technology in the primary treatment of dyeing wastewater.

\section{MATERIALS AND METHODS}

\section{Materials}

The real dyeing wastewater was taken every day from the output of the equalization tank of the wastewater treatment system at Shoelace dyeing manufactory, Ho Chi Minh City, Vietnam, during October $1^{\text {st }}, 2018$ to November $16^{\text {th }}, 2018$ (Toan Hung Co., Ltd., Vietnam). The characteristics of real dyeing wastewater are presented in Table $1 . \mathrm{FeSO}_{4} \cdot 7 \mathrm{H}_{2} \mathrm{O}$ was used as the coagulant in the control experiment. $\mathrm{pH}$ and conductivity were controlled by $\mathrm{NaOH} / \mathrm{H}_{2} \mathrm{SO}_{4}$ and $\mathrm{NaCl}$, respectively. $\mathrm{FeSO}_{4} \cdot 7 \mathrm{H}_{2} \mathrm{O}, \mathrm{NaOH} / \mathrm{H}_{2} \mathrm{SO}_{4}$ and $\mathrm{NaCl}$ were procured from Xilong Chemical Co. Ltd., China.

\section{Experimental Set Up and Analysis Methods}

The experimental bench scale was set up as shown in Fig. 1. In this study, the temperature of wastewater was maintained at the same temperature as the coagulation-flocculation tank in the wastewater treatment system, in the range of $37^{\circ} \mathrm{C}$ $-40^{\circ} \mathrm{C}$ by the electrical heater before supplying into the reaction tank. 8 litres of the wastewater was supplied into a polyacrylic reaction tank $(200 \mathrm{~mm} \times 200 \mathrm{~mm} \times 250 \mathrm{~mm})$ containing a pair of iron plate electrodes. The dimensions of the $5 \mathrm{~mm}$ thick plate electrodes are $150 \mathrm{~mm} \times 200 \mathrm{~mm}$. The gap between the electrodes is $2.5 \mathrm{~cm}$. The electrical current was directly supplied from a laboratory DC power supply (DC Regulated power supply - QJ3010E, China).

Table 1: Characteristics of the real dyeing wastewater.

\begin{tabular}{|llll|}
\hline No. & Parameters & Unit & Range of value \\
\hline 1 & $\mathrm{pH}$ & - & $6.58-7.21$ \\
2 & Colour & $\mathrm{Pt}-\mathrm{Co}$ & $500-2,513$ \\
3 & Conductivity & $\mathrm{mS} / \mathrm{cm}$ & $0.36-0.78$ \\
4 & CODcr & $\mathrm{mg} / \mathrm{L}$ & $430-1,620$ \\
5 & TSS & $\mathrm{mg} / \mathrm{L}$ & 478 \\
\hline
\end{tabular}

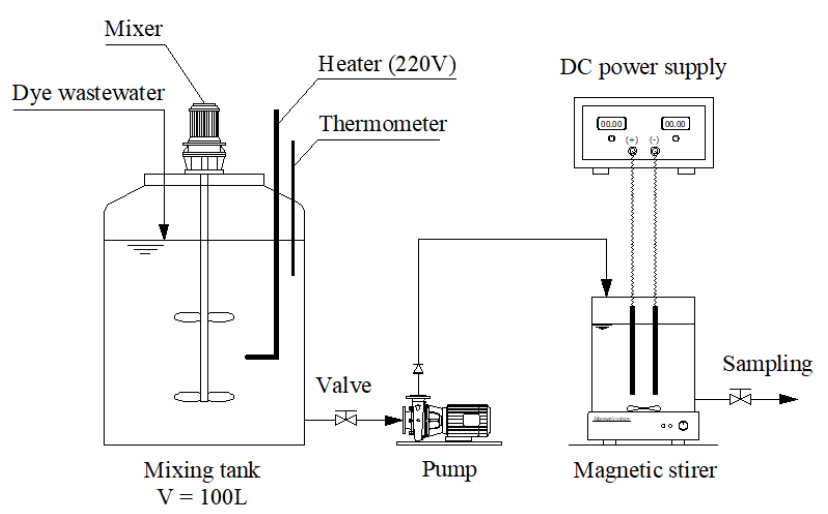

Fig. 1: Schematic diagrams of the electrocoagulation system.

$500 \mathrm{~mL}$ sample was taken and removed the deposited sludge by settling for $60 \mathrm{~min}$. CODcr, colour, and TSS were determined following the Standard Methods for the Examination of Water and Wastewater (APHA 1995). The mass of generated sludge was evaluated by the determination method of TSS in the treated wastewater. The $\mathrm{pH}$ value, temperature, and conductivity were observed by a pH meter (Hana, Germany), thermometer (Okaya Handy Thermo/T200, Japan), conductivity meter (Hana Model 130, Germany), respectively.

Each experiment was repeatedly carried out 3 times and experimental results were analyzed by ANOVA with $\alpha=$ 0.05 . Each experiment time was performed with the same homogeneous wastewater sample.

\section{Calculation Methods}

Removal efficiency, current density, energy consumption, and quantity of dissolved iron were calculated as previous studies of Huynh et al. (2016) and Chaturvedi \& Satish (2013) as follow:

The removal efficiency was calculated as

$$
E_{f f}=\frac{C_{0}-C_{t}}{C_{0}} \times 100
$$

Where, $\mathrm{E}_{\mathrm{ff}}$ is the removal efficiency, \%. $\mathrm{C}_{0}$ and $\mathrm{C}_{\mathrm{t}}$ are pollutants concentration at initial and $\mathrm{t}(\mathrm{min})$ reaction time, respectively.

The current density was calculated through the equation:

$$
C D=\frac{I}{S}
$$

Where, $\mathrm{CD}$ is the current density, $\mathrm{A} / \mathrm{m}^{2}$.

$\mathrm{I}$ is the current (A) and $\mathrm{S}$ is total surface area of the electrodes $\left(\mathrm{m}^{2}\right)$.

Electrical energy consumption by EC process: 


$$
E_{E C}=\frac{E_{c e l l} \times I \times t}{3.6 \times V}
$$

Where, $\mathrm{E}_{\mathrm{EC}}$ is energy consumption for $\mathrm{EC}, \mathrm{Wh} / \mathrm{m}^{3}$. $\mathrm{E}_{\text {cell }}$ is the cell potential $(\mathrm{V}) . \mathrm{I}$ is the total current $(\mathrm{A}) . \mathrm{t}$ is the electrolysis time (s). And V is the working volume of the reactor $(\mathrm{L})$

The dissolved iron quantity in the EC process was calculated by equation .

$$
W=\frac{i \times t \times M}{n \times F}
$$

Where, $\mathrm{W}$ : the amount of dissolution of iron electrode (g); i: current (A); t: reaction time (s); M: Molecular weight of iron; $\mathrm{n}$ : number of electrons in oxidation/reduction reaction, $\mathrm{n}_{\mathrm{Fe}}=2$; F: Faraday's constant, $96485 \mathrm{C} / \mathrm{mol}$.

\section{RESULTS AND DISCUSSION}

\section{The Effect of Current Density}

Current density is the most important factor that affects treatment efficiency and energy consumption in the EC process. In this study, the current density was changed in the range of $12.5 \mathrm{~A} / \mathrm{m}^{2}-33.3 \mathrm{~A} / \mathrm{m}^{2}$. $\mathrm{pH}$ and electrical conductivity were controlled in the range of $6.7-7$ and $2.5 \mathrm{mS} / \mathrm{cm}$, respectively. The reaction time was $20 \mathrm{~min}$. The results indicated that current density significantly affected the colour removal (P-value: 0.000749). Colour removal efficiency increased rapidly from $10.78 \%$ to $90.8 \%$ when current density rose from $12.5 \mathrm{~A} / \mathrm{m}^{2}$ to $20.8 \mathrm{~A} / \mathrm{m}^{2}$ and approximate $94 \%$ with a current density of $25 \mathrm{~A} / \mathrm{m}^{2}$. When current density was continuously increased, colour removal performance was slightly increased. It reached nearly $95 \%$ when the current density rose to $33.3 \mathrm{~A} / \mathrm{m}^{2}$ (Fig. 2a). The higher current density led to consuming more energy. Therefore, the suitable current density value was chosen based on colour treatment efficiency and energy consumption. In this case, the current density of $25 \mathrm{~A} / \mathrm{m}^{2}$ was chosen.

\section{The Effect of pH}

$\mathrm{pH}$ is the key parameter in the electrocoagulation process (Chafi et al. 2011). It possibly directly affects the removal efficiency and chemical consumption to adjust $\mathrm{pH}$ before and after treatment. In this study, the effect of $\mathrm{pH}$ on colour removal efficiency was determined with experimental conditions such as $\mathrm{pH}$ range from 3 to 9 , the current density of 25 $\mathrm{A} / \mathrm{m}^{2}$, the electrical conductivity of $2.5 \mathrm{mS} / \mathrm{cm}$, and reaction time of $20 \mathrm{~min}$. The ANOVA analysis results showed that the effect of $\mathrm{pH}$ on colour treatment was significant with $\mathrm{P}$-value equal to $2.2 \times 10^{-7}$. The observed data is depicted in Fig. $2 b$. The colour removal efficiency rapidly increased when $\mathrm{pH}$ increased from 3 to 7 and reached $94.07 \%$ at $\mathrm{pH} 7$. Then, it slightly increased to $95.59 \%$ when $\mathrm{pH}$ rose from 7 to 9 . It was caused by an acidic medium, $\mathrm{OH}^{-}$ions generated from the cathode reacted with $\mathrm{H}^{+}$ions led to lack of $\mathrm{OH}^{-}$for iron hydroxide formation. When increasing $\mathrm{pH}$, the presence of $\mathrm{OH}^{-}$ions in solution was risen to enhance the formation and precipitation processes of iron ions. In addition, $\mathrm{Fe}^{2+}$ was generated at anode and oxidized to $\mathrm{Fe}^{3+}$ by $\mathrm{Cl}_{2}, \mathrm{HOCl}$, and $\mathrm{ClO}^{-}$in acidic, neutral and alkaline mediums, respectively (Chafi et al. 2011). HOCl is more effective than others. Precipitation of $\mathrm{Fe}(\mathrm{OH})_{2}$ starts at $\mathrm{pH}=8$ and $\mathrm{Fe}(\mathrm{OH})_{3}$ starts at $\mathrm{pH}=3.5$ (Magdalena \& Aneta 2011).

With this actual dyeing wastewater, $\mathrm{pH}$ of influent wastewater nearly equalled to 7 , making the optimal $\mathrm{pH}$ as 7 for treatment by electrocoagulation process using iron electrodes because no or little chemicals were used to adjust $\mathrm{pH}$ value allowing the colour removal efficiency nearly reached the optimal value.

\section{The Effect of Electrical Conductivity}

Electrical conductivity was varied at $1.5 \mathrm{mS} / \mathrm{cm} ; 2.0 \mathrm{mS} / \mathrm{cm}$, $2.5 \mathrm{mS} / \mathrm{cm}$ and $3.0 \mathrm{mS} / \mathrm{cm}$. Current density, $\mathrm{pH}$ and reaction time were fixed at $25 \mathrm{~A} / \mathrm{m}^{2}, 7$ and $20 \mathrm{~min}$, respectively. Although colour removal efficiency in these experiments slightly increased from $92.3 \%$ to $93.7 \%$ when electrical conductivity rose from $1.5 \mathrm{mS} / \mathrm{cm}$ to $2.5 \mathrm{mS}$, ANOVA analysis results indicated that electrical conductivity didn't affect significantly the colour removal, P-value of 0.119 . It was the same with a previous study (Huynh et al. 2016). With the same current density input, the voltage was inversely proportional to electrical conductivity and followed an equation: $y=-2.23 x+16.878\left(\mathrm{R}^{2}=0.9967\right)$. So, the electrical conductivity directly affected energy consumption. Increasing electrical conductivity led to reducing energy consumption in the EC process (Huynh et al. 2016). In this study, electrical conductivity increased from $1.5 \mathrm{mS} / \mathrm{cm}$ to $3.0 \mathrm{mS} / \mathrm{cm}$, energy consumption decreased 2.14 times.

\section{The Effect of Reaction Time}

Reaction time was surveyed from 5 to $35 \mathrm{~min}$ with the current density of $25 \mathrm{~A} / \mathrm{m}^{2}, \mathrm{pH} 7$ and $\mathrm{EC}$ of $2.5 \mathrm{mS} / \mathrm{cm}$. The obtained results presented in Fig. 2c showed that colour removal performance increased markedly in the first 15 min reaction time and archived at nearly $91 \%$. Extending reaction time, treatment efficiency slowly and trivially increased, reached upto $94.5 \%$ within $30 \mathrm{~min}$. It is easy to explain because the amount of dissolved iron ion generated in the first $15 \mathrm{~min}$ reaction time was nearly enough for the coagulation and flocculation process. When reaction time rose to $35 \mathrm{~min}$, colour removal slightly reduced to $93 \%$ caused by residual iron ions in solution. 

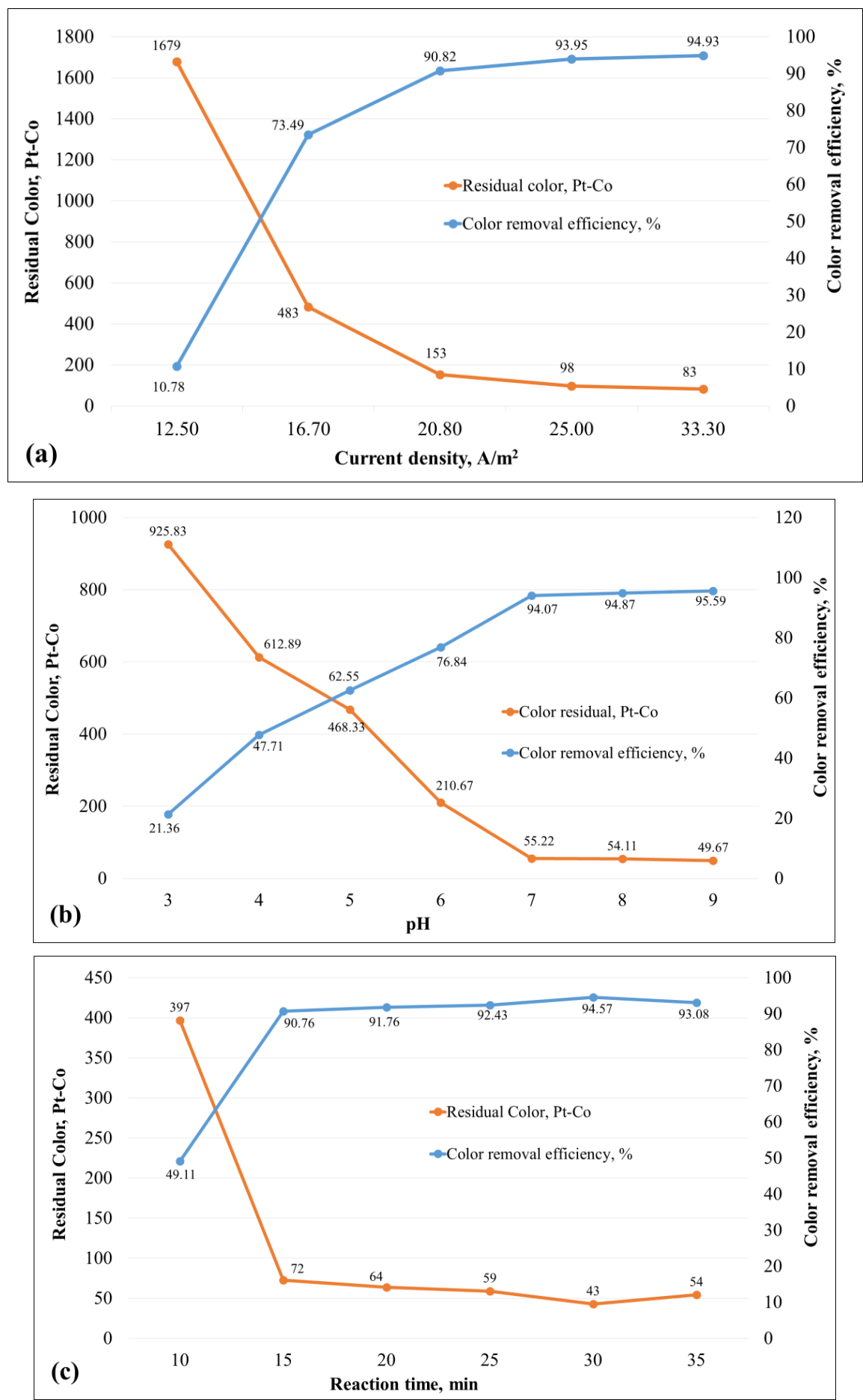

Fig. 2: The average colour removal versus various current density (a), $\mathrm{pH}$ value (b) and reaction time (c).

\section{The Treatment Efficiency by Electrocoagulation}

In order to determine the applicability of this method into wastewater treatment with the real condition at the factory, the testing was performed with the real wastewater taken in different 25 days. The suitable operating parameters were obtained as current density of $25 \mathrm{~A} / \mathrm{m}^{2}$, non-adjusted $\mathrm{pH}$, electrical conductivity of $2.5 \mathrm{mS} / \mathrm{cm}$ and $15 \mathrm{~min}$ reaction 
time. As depicted in Fig. 3, the results showed that the treatment performance was very high and quite stable even though the characteristics of wastewater in input flow much fluctuated. Namely, during the observed period, the $\mathrm{pH}$, colour, CODcr, TSS, and conductivity were in range of 6.58 - 7.21, 725 Pt-Co - 2,513 Pt-Co, $415 \mathrm{mg} / \mathrm{L}$ - 1,692 $\mathrm{mg} / \mathrm{L}, 320 \mathrm{mg} / \mathrm{L}-478 \mathrm{mg} / \mathrm{L}$ and $0.33 \mathrm{mS} / \mathrm{cm}-0.78 \mathrm{mS} /$ $\mathrm{cm}$, respectively. It may be explained as: in the EC process, iron hydroxo complexes formed at the anode has high adsorption properties, forming strong aggregates with pollutants. In addition, the flocculation and adsorption capacity was increased when the pollutant concentration increased due to the higher contacting opportunities between pollutants and coagulants (Kabdasli et al. 2014). It may buffer the fluctuation in inlet flow. The average treatment efficiency was $92.04 \pm 1.21 \%, 65.71 \pm$ $1.47 \%$ and $89.8 \pm 1.2 \%$ corresponding to colour, CODcr, and TSS removal respectively (Table 2). Compared to the discharge standard in Vietnam (QCVN 13:2015/BTNMT, column B), the residual colour and TSS in effluent were lower but residual CODcr was still too much higher than the discharged standard. Therefore, CODcr in the effluent of electrocoagulation reaction was continuously treated by the next stage.
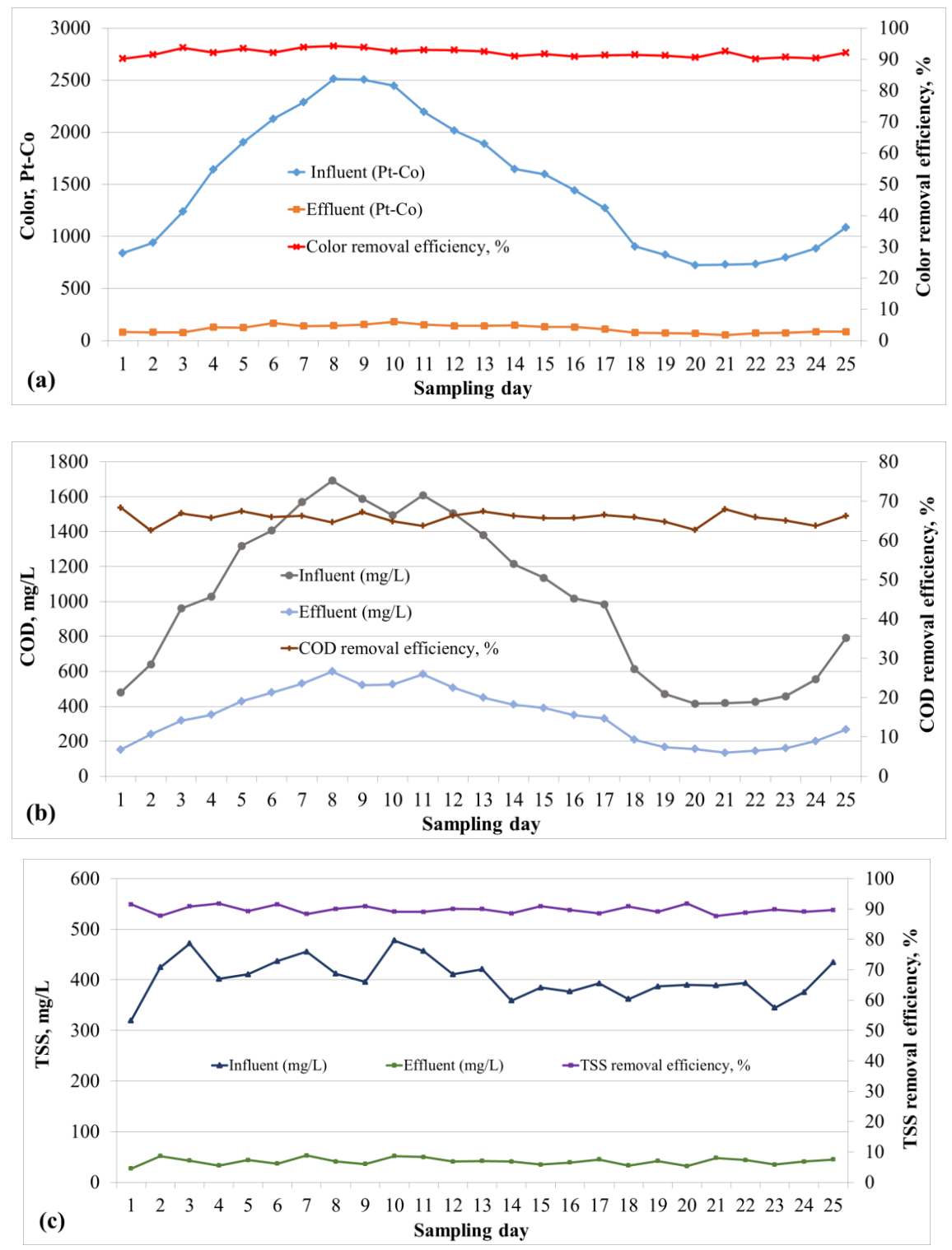

Fig. 3: Variation of concentration and removal efficiencies of Colour, CODcr, TSS. 
The average mass of generated sludge including flotation and sedimentation process was $0.645 \pm 0.054 \mathrm{~g} / \mathrm{L}$ (Table 2). Specific energy consumption was evaluated by equation (3), approximately $1.182 \mathrm{kWh} / \mathrm{m}^{3}$ (Table 2). Iron consumption was determined based on the dissolved iron quantity (Eq. 4) and the total volume of treated wastewater, equal 0.0975 $\mathrm{kg} / \mathrm{m}^{3}$.

\section{Comparisons of Electrocoagulation and Coagulation- Flocculation}

The optimal value of $\mathrm{pH}$ and coagulant dose of $\mathrm{FeSO}_{4} \cdot 7 \mathrm{H}_{2} \mathrm{O}$ in the coagulation-flocculation process using the same raw wastewater used in the electrocoagulation process were determined by Jar-test experiment. The treatment performance, sludge generation, and chemical use were calculated in coagulation-flocculation as well. With the optimal condition, CODcr, TSS and decolourization efficiency reached $56.8 \pm 2.2 \%, 82.4 \pm 2.9 \%$, and $93 \pm 0.6 \%$, respectively. Sludge generation was $1.5 \pm 0.0419 \mathrm{~kg} / \mathrm{m}^{3}$.

The comparison of the electrocoagulation and coagulationflocculation based on treatment efficiency, sludge generation, energy consumption, chemical use, and operation cost were summarized and presented in Table 2. Colour removal efficiency was the same in both methods but CODcr and TSS treatment performances in the electrocoagulation were higher. Sludge generation, chemical use in electrocoagulation were quite less than coagulation-flocculation. This is because, in electrocoagulation, TSS was mainly removed by flotation mechanism so the small flocs formed was immediately floated to the surface by many fine bubbles $\left(\mathrm{H}_{2}\right)$. It did not need as much ion iron to form big flocs to settle to the bottom as in coagulation-flocculation. Moreover, the coagulant in electrocoagulation was directly generated in situ from the anode, did not contain impurify materials. $\mathrm{OH}$ - participated in the flocculation reaction that was formed from $\mathrm{H}_{2} \mathrm{O} . \mathrm{OH}^{-}$ generation had been consumed that buffered the $\mathrm{pH}$ of the solution during electrocoagulation led to the final $\mathrm{pH}$ of effluent changed only slightly. Therefore, there was no need to add chemical to provide $\mathrm{OH}^{-}$and adjust $\mathrm{pH}$ after treating it as the traditional chemical coagulation.

Calculation of the operating cost included the energy cost, iron plate cost, generated sludge treatment cost, and added substances cost. The results showed that the operation cost of electrocoagulation was far much lower than coagulation-flocculation as well, with only $0.517 \mathrm{USD} / \mathrm{m}^{3}$ instead of $1.99 \mathrm{USD} / \mathrm{m}^{3}$ as in conventional coagulation, approximately equal to $1 / 3.5$. The main reasons were because of less generated sludge and no added chemical in the electrocoagulation process (with only small amount of $\mathrm{NaCl}$ ).
Table 2: Comparison of electrocoagulation using iron electrodes and coagulation-flocculation using $\mathrm{FeSO}_{4}$.

\begin{tabular}{|c|c|c|}
\hline Criteria & Electrocoagulation & $\begin{array}{l}\text { Coagulation- } \\
\text { Flocculation }\end{array}$ \\
\hline $\mathrm{pH}$ & 7.0 & 11.0 \\
\hline $\begin{array}{l}\text { Colour removal } \\
\text { efficiency }(\%)\end{array}$ & $92 \pm 1.21$ & $93 \pm 0.61$ \\
\hline $\begin{array}{l}\text { CODcr removal } \\
\text { efficiency }(\%)\end{array}$ & $65.7 \pm 1.47$ & $56.8 \pm 2.2$ \\
\hline $\begin{array}{l}\text { TSS removal efficiency } \\
(\%)\end{array}$ & $89.8 \pm 1.2$ & $82.4 \pm 2.9$ \\
\hline $\begin{array}{l}\text { Sludge generation } \\
\left(\mathrm{kg} / \mathrm{m}^{3}\right)\end{array}$ & $0.645 \pm 0.0543$ & $1.5 \pm 0.0419$ \\
\hline $\begin{array}{l}\text { Specific energy } \\
\text { consumption }\left(\mathrm{kwh} / \mathrm{m}^{3}\right)\end{array}$ & 1.182 & 0.135 \\
\hline $\mathrm{NaOH} 98 \%\left(\mathrm{~kg} / \mathrm{m}^{3}\right)$ & 0 & $0.8 \pm 0.02$ \\
\hline $\mathrm{H}_{2} \mathrm{SO}_{4} 98 \%\left(\mathrm{~kg} / \mathrm{m}^{3}\right)$ & 0 & $0.472 \pm 0.011$ \\
\hline $\mathrm{FeSO}_{4}\left(\mathrm{~kg} / \mathrm{m}^{3}\right)$ & 0 & 0.75 \\
\hline $\mathrm{NaCl}\left(\mathrm{kg} / \mathrm{m}^{3}\right)$ & $1.17 \pm 0.33$ & 0 \\
\hline $\begin{array}{l}\text { Iron plate consumption } \\
\left(\mathrm{kg} / \mathrm{m}^{3}\right)\end{array}$ & 0.0975 & 0 \\
\hline $\begin{array}{l}\text { Operation cost* } \\
\left(\mathrm{USD} / \mathrm{m}^{3}\right)\end{array}$ & 0.517 & 1.99 \\
\hline
\end{tabular}

*The operation cost in both methods was calculated based on the price in Vietnam (Pham Phu Gia Chemical Co. Ltd.).

\section{CONCLUSIONS}

This study found the optimal operating parameters for real dyeing wastewater treatment by electrocoagulation using iron electrodes as follows: current density of $25 \mathrm{~A} / \mathrm{m}^{2}$, nonadjusted $\mathrm{pH}$, electrical conductivity of $2.5 \mathrm{mS} / \mathrm{cm}$ and 15 min reaction time. Electrocoagulation using iron electrodes may be applied in actual dyeing wastewater treatment of shoelace manufactories because it was able to remove colour, CODcr, and TSS in the actual dyeing wastewater with high performance, archived $93 \pm 0.6 \%, 56.8 \pm 2.2 \%$, and $82.4 \pm 2.9 \%$, respectively. Furthermore, it adapted to the various characteristics of influent very well, released less generated sludge, and consumed low operating cost.

\section{ACKNOWLEDGMENT}

We are grateful to Toan Hung Co. Ltd. and Bao Hung Environmental Engineering Corporation for supplying dyeing wastewater and bench-scale reactor.

\section{REFERENCES}

Ahmed, S. N., Mohammed, A. A., Peter, A. A. and Shreeshivadasan, C. 2018. Treatment of textile wastewaster using a novel electrocoagulation reactor design. Intech Open, DOI: 10.5772/intechopen.76876 
Aleboyeh, A., Daneshvar, N. and Kasiri, M.B. 2008. Optimization of C. I. Acid Red 14 azo dye removal by electrocoagulation batch process with response surface methodology. Chemical Engineering and Processing, 47(5): 827-832.

APHA 1995. Standard Method for Examination of Water and Wastewater, 19th ed., American Public Health Association Inc., New York, Part 2120C, 2540D, 2710C, 5220B.

Arslan-Alaton, I., Kabdaşli, I., Vardar, B. and Tünay, O. 2009. Electrocoagulation of simulated reactive dye bath effluent with aluminum and stainless steel electrodes. Journal of Hazardous Materials, 164(2-3): 1586-1594.

Chafi, M., Gourich, B., Essadki, A.H., Voal, C. and Fabregat, A. 2011. Comparison of electrocoagulation using iron and aluminium electrodes with chemical coagulation for the removal of a highly soluble acid dye. Desalination, 281: 285-292.

Charroenlarp, K. and Choyphan, W. 2009. Reuse of dye wastewater through colour removal with electrocoagulation process. Asian J. Energy Environment, 10(4): 250-260.

Chaturvedi and Satish I. 2013. Electrocoagulation: A novel wastewater treatment method. International Journal of Modern Engineering Research, 3(1): 93-100.

Daneshvar, N., Khataee, A.R., Amani Ghadim, A.R. and Rasoulifard, M.H. 2007. Decolorization of C.I. Acid Yellow 23 solution by electrocoagulation process: Investigation of operational parameters and evaluation of specific electrical energy consumption (SEEC). J. Hazard. Mater., 148(3): 566-572.

Daneshvar, N., Sorkhabi, H.A. and Tizpar, A. 2003. Decolorization of orange II by electrocoagulation method. Sep.Purifi.Technol., 31: 153-162.

Hussain, J., Hussain, I. and Arif, M. 2004. Characterization of textile wastewater. Journal of Industrial Pollution Control, 20(1): 137-144.

Huynh, Ngoc-Han T., Duong, Pham-Hung and Yoon, Y.S. 2016. Removal of C.I. Acid Red 114 dye from wastewater by using ozonation and electrocoagulation. Jacobs Journal of Environmental Sciences, 2(2): 019 .
Kabdasli, I., Arslan-Alaton, I., Olmez-Hanci, T. and Tunay, O. 2012. Electrocoagulation applications for industrial wastewaters: a critical review. Environmental Technology Review, 1(1): 2-45.

Kashefialasl, M., Khosravi, M., Marandi, R. and Seyyedi, K. 2006. Treatment of dye solution containing coloured index acid yellow 36 by electrocoagulation using iron electrodes. Int. J. Environ. Sci. Technol., 2(4): 365-371.

Khandegar, V. and Saroha, A.K. 2013. Electrochemical treatment of effluent from small scale dyeing unit. Indian Chem. Eng., 55(2): 1-9.

Khandegar, V. and Saroha, A.K. 2014. Electrochemical treatment textile effluent containing Acid Red 131 dye. J. Hazard. Toxic. Radio. Waste., 18(1): 38-44

Khorram, A. G. and Fallah, N. 2018. Treatment of textile dyeing factory wastewater by electrocoagulation with low sludge settling time: optimization of operating parameters by RSM. Journal of Environmental Chemical Engineering, 6(1): 635-642.

Korbahti, B.K., Artut, K., Gecgel, C. and Ozer, A. 2011. Electrochemical decolorization of textile dyes and removal of metal ions from textile dye and metal ion binary mixtures. Chem. Eng. J., 173(3): 677-688.

Magdalena, B. and Aneta, P. 2011. Study of $\mathrm{pH}$ influence on selective precipitation of heavy metals from acid mine drainage. Chemical Engineering Transaction, 25: 345-350.

Parsa, J.B., Vahidian, H.R, Soleymani, A.R. and Abbasi, M. 2011. Removal of Acid Brown 14 in aqueous media by electrocoagulation: optimization parameters and minimizing of energy consumption. Desalination, 278(1-3): 295-302.

Yang, C.L. and McGarrahan, J. 2005. Electrochemical coagulation for textile effluent decolorization. J. Hazard. Mater., B127(1-3): 40-47.

Yuksel, E., Eyvaz, M. and Gurbulak, E. 2013. Electrochemical treatment of colour index Reactive Orange 84 and textile wastewater by using stainless steel and iron electrodes. Environ. Prog. Sust. Energy, 32(1): 60-68.

Wang, J., Tan H. C., Zhang, Y. L. and Pan Y. Z. 2016. The treatment of high concentration dyeing wastewater with pulse current electrocoagulation. Morden Applied Science,10(5). 